\title{
Rebecca Williams, Everybody Hurts
}

\begin{abstract}
Alison Morrow
Williams, Rebecca, eds. Everybody Hurts: Transitions, Endings, and Resurrections in Fan Cultures (lowa City: University of lowa Press, 2018).

What happens to a fandom when the object of the fandom comes to an end? Academic studies traditionally have focused on the creation of new fans and fandoms or on the lifespans of active fandoms, but little attention has been paid to the endings that cause fandoms to either transition or dissipate. The engaging and topical Everybody Hurts: Transitions, Endings, and Resurrections in Fan Cultures, edited by Rebecca Williams, explores the various fan responses to the ends of their favorite bands, stories, and spaces. Williams organizes the book through four thematic thrusts: "Exploring Music Fandom," "Televisual Anniversaries, Endings and Fan/Producer Relationships," "Fan Works, Adaptations, and Endings," and "Fandom and the Loss of Space and Place." The contributing authors examine both communal fandoms and individual fan approaches to fan objects, leading to better understanding of how fan endings can threaten a fan's self-identity and membership in a collective, and the fan responses to those threats.
\end{abstract}

While Williams never explicitly states it, the chapters of the book largely find three different fan responses to endings: nostalgia, when an ending signals the end of an era, such as the closing of Blockbuster video rental stores; rejection, when fans reject the actions of a creator and walk away from the fandom; and a renewed commitment to the fandom, often seen in fans of Star Trek, for example. The responses, the authors suggest, depend on the ending of the fan object itself and the circumstances surrounding that ending. These differing responses appear throughout the volume.

Part One of the book explores music fandoms. Lucy Bennett's study of online forums dedicated to the memory of R.E.M. finds that participants often use these forums to share memories of the band's performances. Simone Driessen examines fans of the band Backstreet Boys who have recommitted to their fandom in their adult life. In perhaps the most relevant and timely chapter in the book, Bethan Jones' "'My Music Was on Shuffle, One of Their Songs Came on, and I Had to Hit Next..."' (chapter 3) explores how fans react when a band member does something inexcusable - as in the case of the lead singer of Lostprophets, who was found guilty of pedophilia and other sexual perversions - and breaks up the band. Jones discovers that fans mostly moved from disbelief when the arrest happened, to disgust when the lead singer, lan Watkins, was found guilty. For these (former) fans, the memories of Lostprophets' music is tinged with loneliness and sadness - sadness both for the other band members and sadness for themselves, because Watkins' behavior amounted to a betrayal of the fans, making it impossible to enjoy the band's music and tainting their memories of experiencing that music. In the "Me Too" era, this chapter has extra relevance for those fandoms struggling with ethical responses to accusations against creators of their beloved stories.

Part Two explores endings on television, including both endings of shows and endings of specific fan-favorite characters. Of particular note, Paul Booth's "Fan Euthanasia" (chapter five) eloquently explores situations where fans advocated for long-running shows to end, suggesting that academia should move away from a love-hate binary in fandom studies. Instead, Booth suggests, researchers should consider that fans' attitudes change over the lifespan of a television show, and fan interaction is both more involved and more complex than a simple binary implies. Evelyn Deshane's "Hannibal's Refrigerator" (chapter eight) more closely examines an instance where a fan community rejected the death of a character on the show Hannibal, and remarkably, the show's creator responded to fan outrage to better engage with and learn from the fans. 
Part Three focuses on fan works that either create a new, more acceptable ending or extend the fan universe to live on indefinitely. Nicolle Lamerichs' "When Production is Over" (chapter ten) looks at fan edits of shows with contested narrative endings and finds that fan edits that alter those canonical endings exist to correct perceived wrongs of the creators and create narrative closure for the fandom. In "Creating Canon through Kickstarter" (chapter eleven), Nichola Dobson explores fan-created and funded web shows based on the Star Trek universe, and notes that because of fan acceptance, these shows have become canon without "official" approval from the copyright holders. Fans becoming authors without the official label of "author" should be of note to those studying the creation of mythology as well as those in cultural and fan studies.

Perhaps the biggest departure from traditional fan studies, Part Five probes fandoms related to physical spaces, from the end of a Disney ride in "Replacing Maelstrom" (chapter twelve), to the end of video stores in "Internet Killed the Video Store" (chapter fourteen), and finds in fan responses both resistance to change and nostalgia for what used to be. In "The World's Turned Inside Out, and We Can Never Go Home Anymore" (chapter thirteen), Emily Garside explores the closing of an experimental theater show which developed a fan community because of its individualized interactions with theatergoers and actors in a site-specific space. Garside finds that the announced closure of the show drew fans back to enjoy the experience one more time, and after the closing, fans gathered in online forums to reminisce about the physical space, similar to how fans shared memories of specific band performances in Lucy Bennett's opening chapter about R.E.M.

In her afterword, Kristina Busse considers potential criticisms of this collection, the most important of these being that scholarship in fandom tends to focus on positive fan interactions rather than negative ones, such as online bullying between fans. Future research would benefit from a more rounded look at the entirety of fandom reactions to endings, both good and bad. Alternately, only one chapter in this volume studies a fandom outside of the West (in "The Repurposed Fantasy" (chapter nine), Anya Benson examines Japanese fan-created media mixes). ${ }^{[1]}$ Additional study of other cultures with differing understandings of what constitutes an ending would prove valuable.

If there is one stylistic quibble with this collection, it may be in the ordering of the final chapters - while Kathleen Williams' final chapter about video stores elucidates important fan reactions to the end of physical video media and the shift to streaming, Garside's chapter about the closing of a show better bookends the volume and offers a deeper philosophical look at endings within fandom. There is irony, however, in criticizing the ending of a book about endings.

Busse compares fan endings to the emotions involved in the ending of a love affair, and her example is apt. In this sense, an end in a fan community and the fans' reactions become a journey in love and loss - a metaphor for life. The reactions of the fans, as related in this volume, however, resemble the grieving process for a death and bring home the title. However it ends, the end of a fan object causes everyone to hurt, and precipitates differing responses to cope with that grief.

\section{Notes}

1. And, in fact, only two looked outside of Great Britain and the United States.

\section{Cite this Essay}

Morrow, Alison. "Rebecca Williams, Everybody Hurts." Rhizomes: Cultural Studies in Emerging Knowledge, no. 35, 2019, doi:10.20415/rhiz/035.r07 
Editors: Ellen Berry and Carol Siegel. Reviews editor: Craig J. Saper. Technical editor: Helen J Burgess 